\title{
NAFTA and the Geography of North American Trade
}

\author{
Howard J. Wall
}

T his paper estimates the effects of the North American Free Trade Agreement (NAFTA) on the geographic pattern of North American trade. Specifically, it looks at the effects of NAFTA on aggregate trade flows between subnational regions within North America and between North American regions and the non-NAFTA world. The importance of a regional analysis of the effects of NAFTA is evident from the variety of regional post-NAFTA experiences. Between 1993 and 1997, real trade between Canada and the United States increased by more than 50 percent. Over the same period, Central Canadian exports to the Southwest and Rocky Mountain regions of the United States and Eastern Canadian exports to the Southeast of the United States all increased by more than 110 percent. In contrast, Eastern Canadian real imports from the Great Lakes, Plains, and Southeast regions of the United States were actually lower in 1997 than they were in 1993. Further, although real Canadian exports to Mexico increased by 46 percent over the period, those from Western Canada rose by over 90 percent while those from Eastern Canada rose by less than 1 percent. ${ }^{1}$

Viner (1950) established the general principle that the welfare effect of joining a preferential trading area (PTA) such as NAFTA is ambiguous. This is because PTAs create a distortion between the trading conditions that member and nonmember countries face. In a simple partial-equilibrium model under perfect competition, a PTA will increase trade between members, whether countries or regions,

\footnotetext{
See Tables A1 through A4 in Appendix A for the available percent differences in real region-to-region, region-to-country, and country-tocountry trade between 1993 and 1997. See also Krueger (2000) for a broader discussion of the changes in trade between NAFTA partners.

Howard J. Wall is a research officer at the Federal Reserve Bank of St. Louis. He thanks Cletus Coughlin and seminar participants at the Spring 2000 Midwest International Economics Conference at the University of Kentucky, West Virginia University, the Federal Reserve System Regional Meetings, and the Association for University Business Economic Research Conference for their comments. Ling Wang provided research assistance; Abbigail J. Chiodo provided editorial assistance.

(1) 2003, The Federal Reserve Bank of St. Louis.
}

because the tariff between them has been eliminated (trade creation). If the most efficient producer of a good is outside the PTA, the effect is to import more from the less efficient member-producer (trade diversion). The net effect of a PTA on trade volume (as a proxy for welfare) would depend, therefore, on the relative sizes of trade creation and trade diversion.

Despite the presumed certainty of trade creation and trade diversion, the ways in which integration affects trade are many and varied, and few fit into the simple Vinerian dichotomy. One significant nonVinerian way for integration to affect trade volumes is through increasing returns to scale, a topic typically absent from the empirical literature, although prominent in the theoretical literature. It has also been central to the public discussion of North American integration, as, for example, Canadian firms have long argued that access to the U.S. market would allow them to exploit economies of scale. This access would allow them to increase their exports not only to the rest of North America, but also to the rest of the world. Increasing returns also affects the volume of trade in inputs and intermediate goods used by increasing-returns industries. This is because firms that expand production and exploit economies of scale need to purchase more inputs and intermediate products, which might be imported from inside or outside North America. Thus, in contrast with the Vinerian effects, with economies of scale, NAFTA may increase trade between members and between members and nonmembers.

The effects from trade creation, trade diversion, and scale economies arise whether one looks at trade from a national or a regional standpoint, and they would drive much of the regional variation in the effects of a PTA. As with countries, regions differ in their abilities to match their comparative advantages to the preferences of consumers in other member and nonmember regions. However, the recent literature under the rubric of the "new economic geography" suggests that things are actually much more interesting when account is taken of firms changing their locations as a response to joining a PTA. This literature, spearheaded by Krugman 
(1991a,b), models various ways in which production patterns (and therefore trade patterns) can change with integration because of its effects on firms' optimal location decisions. ${ }^{2}$

One of the reasons that a PTA affects geographic trade patterns is that it alters the spatial distributions of firms' customers and suppliers. For example, consider a firm initially located in Massachusetts. By adding Mexico to the Canada-United States Free Trade Area, the spatial distributions of the firm's customers and suppliers are shifted southward, creating greater incentive for the firm to move closer to Mexico, if not into Mexico itself. If the firm relocates, regional trade patterns will change because goods that were exported from Massachusetts to Canada, Mexico, and the rest of the world would instead be exported from, say, Arizona. At the same time, because the firm has moved across the continent, it is in a better position for exporting to Asia and a worse position for exporting to Europe. Also, the firm would be more likely to import intermediate products from Asia, and the regional import pattern would change accordingly.

A second reason that a PTA affects geographic trade patterns is that it expands the set of possible places for firms to locate. Under NAFTA, Canadian and U.S. firms that move to Mexico can do so without losing tariff-free access to their domestic markets. This affects intra-NAFTA trade by switching what had been exports, say, from Canada to the United States and Mexico, into exports from Mexico to the United States and Canada. Extra-NAFTA trade would also be affected, as a firm that was exporting from Canada to the rest of the world would instead export from Mexico. The new economic geography literature suggests that these location effects are much stronger when there are cross-firm linkages whereby a firm's marginal costs are lower when other firms are nearby. With these linkages there is a tendency for linked firms to cluster, creating industry centers.

These examples are by no means exhaustive, but they do provide sufficient illustration of the theoretical inadequacies of the Vinerian dichotomy. In this vein, my estimates of the regional effects of NAFTA serve a more general purpose. Specifically, they provide support for the hypothesis that, because it does not account for the spatial or geographic effects of integration, standard customs union theory

\footnotetext{
2 Also see Krugman (1998) and Fujita, Krugman, and Venables (1999). Hanson (1996, 1998a, 1998b) and Krugman and Hanson (1994) discuss the effects that previous stages of North American integration have had on location decisions.
}

(the Vinerian dichotomy) is inadequate for capturing the effects of preferential trading areas. The geographic approach is a break from standard empirical analyses of PTAs in that it recognizes that the nation is not always the relevant unit of reference for international trade (Krugman, 1991a). I find ample evidence that the effects of NAFTA have not conformed to the Vinerian dichotomy and conclude that the customs union theory needs to be reworked to include a substantial accounting of geography and scale economies.

The empirical model that I use, the gravity model, has become the workhorse for estimating the effects of PTAs on trade volume. In a gravity model, bilateral trade is assumed to be an increasing function of the national incomes of the trading partners and a decreasing function of the distance between them. The effects of PTAs are modeled with dummy variables. For my present purposes, the gravity model has advantages and disadvantages, both arising from its simplicity. While it allows me to examine the effects of NAFTA on a large number of trading combinations, it is not versatile enough to attribute the effects on aggregate trade to trade creation, trade diversion, the mobility of firms, agglomeration, etc.

From a practical standpoint, the major advantage of the gravity model is that the researcher does not need to specify the underlying trade processes, although that it is largely ad hoc has meant that the gravity model has met with much suspicion by international trade theorists. Deardorff (1984, p. 504), however, concluded that gravity models tell us "something very important about what happens in international trade, even if they do not tell us why." Recently, though, the gravity model has "gone from an embarrassing poverty of theoretical foundations to an embarrassment of riches." ${ }^{3}$ In fact, as shown by Bergstrand $(1985,1989)$ and Deardorff (1998), among others, the gravity model can be derived within a variety of standard theoretical frameworks. The estimates I present below demonstrate vividly the greatest strengths and weaknesses of the gravity model. On the one hand, its simplicity allows for the estimation of a large number of region-to-region NAFTA effects that would be extremely difficult to obtain using any other method. On the other hand, it provides little guidance to explain why the NAFTA effects occur. Nevertheless, the results do suggest that geography may have played an extremely large role.

\footnotetext{
3 Frankel (1998, p. 2).
} 
Two recent gravity studies also look at the effects of NAFTA on aggregate trade between NAFTA members, both using national-level data only. Krueger (1999) found that NAFTA has had no statistically significant effect on intra-North American trade, although she did find a statistically significant decrease in imports from Europe. Gould (1998), who only considered intra-North American trade, found that NAFTA has had a significant effect on trade between the United States and Mexico, but not on trade between the United States and Canada or Mexico and Canada. ${ }^{4}$ One reason for these lukewarm results is the small number of observations of postNAFTA national-level trade volume. As will be apparent below, this is not a problem in the present study.

\section{THE DATA}

In constructing my empirical model, many of the choices are driven by the availability of data on North American regional trade. This study is based on a unique dataset from Statistics Canada on provincial merchandise imports and exports to and from all 50 U.S. states, the District of Columbia, and most countries of the world. It is the same dataset that formed the basis of earlier studies of the effect of the United States-Canada border on trade (McCallum, 1995, Helliwell, 1996). However, because I do not wish to consider the additional complication of the border effect, I do not include data on intraprovincial trade.

My dataset includes bilateral provincial trade between all provinces and the 50 U.S. states, the District of Columbia, Mexico, and 8 non-NAFTA countries: China, France, Germany, Hong Kong, Japan, Korea, the Netherlands, and the United Kingdom. I also include data from World Trade Flows on bilateral trade between the non-NAFTA countries. ${ }^{5}$ The data on trade between non-NAFTA countries are needed as a control under the assumption that trade between them has not been affected by NAFTA. ${ }^{6}$

\footnotetext{
4 For estimates of the industry-level partial-equilibrium effects, see Krueger (1999), Busse (1996), Devadoss, Kropf, and Wahl (1995), Espinosa and Noyola (1997), Hinojosa-Ojeda et al. (1996), Karemera and Ojah (1998), USITC (1997), and Wylie (1995). Also, see the volume edited by Kehoe and Kehoe (1995) for applied general-equilibrium estimates.

5 See Feenstra (2000) and Feenstra, Lipsey, and Bowen (1997) for descriptions of this dataset.

${ }^{6}$ Of course, in the most general of general-equilibrium models, NAFTA also would affect trade between any two non-NAFTA countries. Nonetheless, these effects are small enough to ignore for present purposes.
}

The two data shortcomings are the absence of comparable state-level data on U.S. merchandise trade with countries other than Canada and the absence of Mexican state-level data of any sort. ${ }^{7}$ Nonetheless, the dataset is extremely rich, providing a panel of 1272 bilateral trading pairs, with 11,340 observations. ${ }^{8}$ Note that all values in the dataset are transformed into real 1992 Canadian dollars at market exchange rates. ${ }^{9}$ I use market exchange rates rather than purchasing-power-parity exchange rates to reflect the fact that what matters for international trade is the size of a country's economy at world prices, rather than domestic prices. Thus, in the spirit of gravity models, fluctuations in the value of a country's currency are captured by fluctuations in its economic size.

In principle, I could estimate the model with every state, province, and non-NAFTA country as its own region. However, I need to collect the states and provinces into regions to yield enough observations to provide reliable estimates of the regional NAFTA dummies. Thus, using standard regional designations from the U.S. Bureau of Economic Analysis and Statistics Canada, I divide North America into 13 regions. Three are in Canada (Eastern, Central, and Western Canada), nine are in the United States (New England, Mideast, Great Lakes, Plains, Southeast, South Central, Southwest, Rocky Mountain, Far West), and Mexico is treated as one region. ${ }^{10}$ I also divide the 8 non-NAFTA countries into two regions: Asia and Europe. So, although my model allows for the effects of NAFTA to differ across regions, the estimated effects of NAFTA are assumed to be uniform across the locations (states, provinces, or countries) within a region.

Given the dataset, there are 39 pairs of regions. Because I have data for both directions of trade for all 39 pairs, there are 78 unidirectional trading pairs - 60 for intra-NAFTA trade, 8 for imports into North America, 8 for exports from North America,

7 The United States does collect state-level export data, but it is not compatible with the Canadian data. See Coughlin and Wall (2003) for an analysis of NAFTA and U.S. state exports.

8 Of the 1272 pairs, 1020 are for trade between U.S. states and Canadian provinces (51 states, 10 provinces, 2 directions of trade), 20 are for trade between Mexico and the Canadian provinces, 16 are for trade between Mexico and the 8 non-NAFTA countries, 160 are for trade between the Canadian provinces and the non-NAFTA countries, and 56 are for trade between the non-NAFTA countries.

9 See the data appendix for details about data sources.

${ }^{10}$ See the data appendix for the assignment of states, provinces, and countries to regions. 
and 2 for trade between Asia and Europe. To estimate these interregional effects, I include regionpair dummy variables for all 76 of the region pairs that include at least one North American region.

\section{ESTIMATION}

I estimate bilateral trade with a gravity equation specifying the level of exports from location $i$ to location $j$ as a function of their gross domestic products (GDPs), the distance between them, and any number of fixed cultural and geographic measures such as language and contiguity. Departing somewhat from the standard gravity model, I do not impose the restriction that the intercepts be the same across pairs of locations and directions of trade. This follows Mátyás (1997), Bayoumi and Eichengreen (1997), Cheng and Wall (2002), Glick and Rose (2001), Pakko and Wall (2001), and Egger (2002) who argue that gravity models that restrict the intercepts to equality suffer from heterogeneity bias.

The gravity equation I estimate is

(1)

$$
\begin{aligned}
& \ln \left(1+x_{i j t}\right) \\
& \quad=\alpha_{0}+\alpha_{i j}+\lambda t+\beta \ln Y_{i t}+\gamma \ln Y_{j t}+\delta \ln d i s t_{i j} \\
& \quad+\mu^{\prime} \mathbf{E U}+\delta^{\prime} \mathbf{I n t r a N A}+\theta^{\prime} \mathbf{N A I m p}+\rho^{\prime} \mathbf{N A E x p}+\varepsilon_{i j t},
\end{aligned}
$$

where $x_{i j t}$ is real exports from location $i$ to location $j$ in year $t, \alpha_{0}$ is the shared intercept, $\alpha_{i j}$ is the tradingpair intercept (without the restriction that $\alpha_{i j}=\alpha_{j i}$ ), $\lambda t$ is the shared time trend, dist $t_{i j}$ is the distance between $i$ and $j$, and $Y_{i t}$ and $Y_{j t}$ are the real GDPs of $i$ and $j .{ }^{11}$

IntraNA is a $60 \times 1$ vector of dummy variables to capture the effects of NAFTA on both directions of trade between the 30 region-to-region combinations within North America. An element of IntraNA takes the value of one when the observation is of post-NAFTA trade from the element's exporting region to its importing region and is zero otherwise. Similarly, NAImp is the $8 \times 1$ vector of dummy variables to capture the effects of NAFTA on North American regional imports from Asia and Europe, and NAExp is the $8 \times 1$ vector of dummy variables to capture the effects of NAFTA on North American regional exports to Europe and Asia.

Because the four European countries in the

\footnotetext{
${ }^{11}$ Note that because some observations are of zero trade, the dependent variable is the log of 1 plus exports. Having censored data normally requires Tobit estimation, but for gravity models this has typically made little difference (Eichengreen and Irwin, 1998).
}

sample are also members of the European Union $(\mathrm{EU})$, the regression equation also includes dummy variables to control for the transformation of the European Community (EC) into the EU in 1993. Specifically, EU is a vector of three dummy variables for post-EU trade: one each for trade between members, trade from a nonmember to a member, and trade from a member to a nonmember. Note that, because the model has trading-pair intercepts and because the four European countries in the dataset were all members of the EC at the start of the sample period, the EU dummy variables account only for the differences between the two regimes. The effect of the EC is already accounted for by the relevant trading-pair intercepts.

The least-squares estimates are provided in Tables 1 and 2A. Distance and other standard variables in gravity models, such as contiguity and common language, cannot be estimated separately because they are all fixed over time. Because of this, they are subsumed into the trading-pair intercept, along with all other observable and unobservable fixed factors related to history, culture, preferences, etc., that would make exports from $i$ to $j$ differ from trade between other trading pairs.

The results in Table 1 are as expected for a gravity equation: The higher the incomes of the two partners are, the more they trade. Of the three EU dummies, only the one for the effect of the EU on EU exports to the rest of the world is statistically significant. It suggests that the change in regime from the EC to the EU increased EU exports to nonmembers by 7.8 percent $\left(100 \times\left(\mathrm{e}^{7.5}-1\right)\right)$. In contrast, the estimated coefficients on the other two EU dummies suggest that the EU had little effect on intra-EU trade or on EU imports from nonmembers. Keep in mind, though, that because the sample is extremely limited in its coverage of European trade, these results are far from definitive. The coefficient on the time trend is positive, indicating a common trend toward more trade, even without NAFTA, although it is statistically insignificant.

My primary interest is in the signs and levels of the estimated coefficients on the interregional NAFTA dummies, which are listed in Table $2 \mathrm{~A}$ and converted into percentage changes in Table 2B. In addition, Tables 3 and 4 provide various aggregations of the interregional percentage changes, which are obtained by applying the estimated percentage changes to the average real post-NAFTA trade volumes for 1994-98. 


\section{Table 1}

\section{Regression Results, Dependent Variable $=\ln (1+$ Exports $)$}

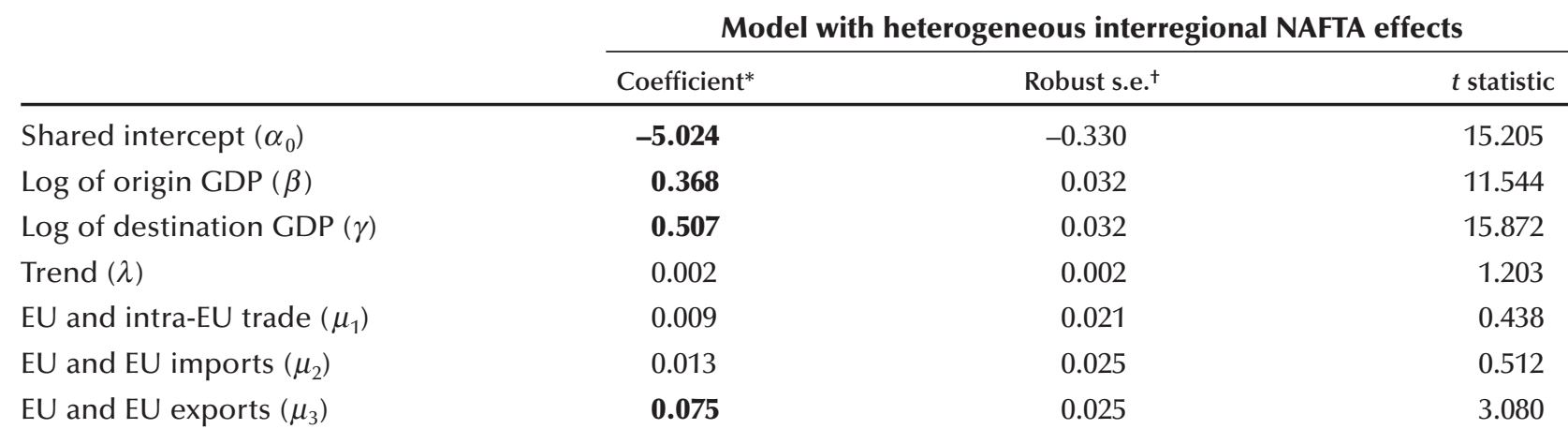

IntraNA, NAImp, NAExp $(\delta, \theta, \rho)$

See Table 2

11340 observations, $\bar{R}^{2}=0.981, \mathrm{~F}(82,9986)=66.79$

NOTE: The 1272 bilateral region-pair intercepts are suppressed for space considerations.

*Bold indicates significance at the 5 percent level.

tWhite-corrected standard errors.

\section{TRADE BETWEEN NORTH AMERICAN REGIONS}

\section{Canada-United States Trade}

According to my results as summarized in Table 3A, NAFTA increased Canadian exports to the United States by 29 percent and Canadian imports from the United States by 14 percent. From the perspective of the three Canadian regions, positive NAFTA effects were far from universal. As shown in Tables 2A and B, all 18 of the estimated effects of NAFTA on trade between Eastern Canada and a U.S. region are negative, and all but one are statistically significant. In total, the results indicate that Eastern Canadian exports to the United States were 9 percent lower because of NAFTA, with the largest decreases being to the Rocky Mountain and Plains regions.

Similarly, Eastern Canadian imports from the United States fell by 13 percent, with imports from all U.S. regions seeing roughly similar decreases.

In stark contrast with the results for Eastern Canada, the results for Central Canada indicated that NAFTA led to large increases in trade with the United States. They suggest that total Central Canadian exports to the United States rose by 43 percent because of NAFTA, with all but one U.S. region seeing a large increase. On the import side, NAFTA increased Central Canadian imports from the United States by 18 percent. Although the effects on imports from the Rocky Mountain region and the Far West were small and statistically insignificant, the effects on imports from the other seven regions were all positive.

The mixed region-to-region effects for Western Canada mean that the estimated effect of NAFTA on the region's total trade with the United States was effectively zero. Nonetheless, there were large differences across U.S. regions in the estimated effects of NAFTA on Western Canada's trade. The one positive and statistically significant effect was to the Great Lakes region. The four negative and statistically significant effects were for exports to the Northeast, Mideast, Southeast, and South Central regions. For Western Canadian imports from the United States, only the estimated effect on imports from the Great Lakes region was positive and statistically significant. The four regions with negative and statistically significant effects were the Northeast, South Central, Rocky Mountain, and Far West regions.

Table 3B provides the region-to-region effects aggregated across the three Canadian regions for each of the U.S. regions. From this perspective, it is easy to see that the estimated positive effect of NAFTA on trade between Canada and the United States was fairly general across U.S. regions. Exceptions to this were the Rocky Mountain region, with an estimated 6 percent fall in exports to Canada with no change in imports, and the Far West, with 
Coefficients on Region-to-Region NAFTA Dummies

\begin{tabular}{|c|c|c|c|c|c|c|c|c|c|c|c|c|c|c|c|}
\hline $\begin{array}{l}\text { Origin/ } \\
\text { destination }\end{array}$ & $\begin{array}{l}\text { Eastern } \\
\text { Canada }\end{array}$ & $\begin{array}{l}\text { Central } \\
\text { Canada }\end{array}$ & $\begin{array}{c}\text { Western } \\
\text { Canada }\end{array}$ & $\begin{array}{c}\text { New } \\
\text { England }\end{array}$ & $\begin{array}{l}\text { Mid- } \\
\text { east }\end{array}$ & $\begin{array}{l}\text { Great } \\
\text { Lakes }\end{array}$ & Plains & $\begin{array}{c}\text { South- } \\
\text { east }\end{array}$ & $\begin{array}{l}\text { South } \\
\text { Central }\end{array}$ & $\begin{array}{c}\text { South- } \\
\text { west }\end{array}$ & $\begin{array}{c}\text { Rocky } \\
\text { Mountain }\end{array}$ & $\begin{array}{c}\text { Far } \\
\text { West }\end{array}$ & Mexico & Europe & Asia \\
\hline Eastern Canada & & & & $\begin{array}{r}-\mathbf{0 . 1 1 5} \\
0.022\end{array}$ & $\begin{array}{r}-0.034 \\
0.026\end{array}$ & $\begin{array}{r}\mathbf{- 0 . 0 5 1} \\
0.020\end{array}$ & $\begin{array}{r}\mathbf{- 0 . 1 9 3} \\
0.011\end{array}$ & $\begin{array}{r}-\mathbf{0 . 1 0 6} \\
0.019\end{array}$ & $\begin{array}{r}-\mathbf{0 . 1 5 7} \\
0.015\end{array}$ & $\begin{array}{r}\mathbf{- 0 . 0 9 4} \\
0.035\end{array}$ & $\begin{array}{r}-\mathbf{0 . 2 2 4} \\
0.013\end{array}$ & $\begin{array}{r}-\mathbf{0 . 1 6 4} \\
0.013\end{array}$ & $\begin{array}{r}-\mathbf{0 . 1 5 9} \\
0.035\end{array}$ & $\begin{array}{r}-\mathbf{0 . 1 7 9} \\
0.030\end{array}$ & $\begin{array}{r}\mathbf{- 0 . 1 7 4} \\
0.025\end{array}$ \\
\hline Western Canada & & & & $\begin{array}{r}-\mathbf{0 . 1 2 1} \\
0.019\end{array}$ & $\begin{array}{r}-\mathbf{0 . 0 7 5} \\
0.031\end{array}$ & $\begin{array}{r}\mathbf{0 . 0 8 5} \\
0.040\end{array}$ & $\begin{array}{l}0.015 \\
0.041\end{array}$ & $\begin{array}{r}-\mathbf{0 . 0 9 2} \\
0.017\end{array}$ & $\begin{array}{r}-\mathbf{0 . 0 7 7} \\
0.021\end{array}$ & $\begin{array}{r}-0.015 \\
0.030\end{array}$ & $\begin{array}{l}0.052 \\
0.034\end{array}$ & $\begin{array}{l}0.017 \\
0.022\end{array}$ & $\begin{array}{l}\mathbf{0 . 2 6 9} \\
0.052\end{array}$ & $\begin{array}{r}-0.060 \\
0.032\end{array}$ & $\begin{array}{r}\mathbf{- 0 . 1 0 7} \\
0.034\end{array}$ \\
\hline Mideast & $\begin{array}{r}-\mathbf{0 . 1 1 6} \\
0.011\end{array}$ & $\begin{array}{l}\mathbf{0 . 1 0 8} \\
0.043\end{array}$ & $\begin{array}{r}-0.012 \\
0.018\end{array}$ & & & & & & & & & & & & \\
\hline Great Lakes & $\begin{array}{r}-\mathbf{0 . 1 3 9} \\
0.014\end{array}$ & $\begin{array}{l}\mathbf{0 . 2 2 9} \\
0.040\end{array}$ & $\begin{array}{l}\mathbf{0 . 1 1 0} \\
0.024\end{array}$ & & & & & & & & & & & & \\
\hline Plains & $\begin{array}{r}-\mathbf{0 . 1 5 8} \\
0.010\end{array}$ & $\begin{array}{l}\mathbf{0 . 0 8 2} \\
0.034\end{array}$ & $\begin{array}{l}0.023 \\
0.020\end{array}$ & & & & & & & & & & & & \\
\hline South Central & $\begin{array}{r}-\mathbf{0 . 1 3 7} \\
0.011\end{array}$ & $\begin{array}{l}\mathbf{0 . 2 4 5} \\
0.033\end{array}$ & $\begin{array}{r}-\mathbf{0 . 0 3 8} \\
0.015\end{array}$ & & & & & & & & & & & & \\
\hline Southwest & $\begin{array}{r}-\mathbf{0 . 1 6 1} \\
0.014\end{array}$ & $\begin{array}{l}\mathbf{0 . 0 9 3} \\
0.040\end{array}$ & $\begin{array}{r}-0.007 \\
0.022\end{array}$ & & & & & & & & & & & & \\
\hline Rocky Mountain & $\begin{array}{r}-\mathbf{0 . 1 8 0} \\
0.011\end{array}$ & $\begin{array}{r}-0.022 \\
0.036\end{array}$ & $\begin{array}{r}\mathbf{- 0 . 1 1 5} \\
0.015\end{array}$ & & & & & & & & & & & & \\
\hline Far West & $\begin{array}{r}-\mathbf{0 . 1 5 7} \\
0.013\end{array}$ & $\begin{array}{l}0.023 \\
0.030\end{array}$ & $\begin{array}{r}-\mathbf{0 . 0 6 2} \\
0.016\end{array}$ & & & & & & & & & & & & \\
\hline Mexico & $\begin{array}{r}-\mathbf{0 . 1 3 2} \\
0.056\end{array}$ & $\begin{array}{l}\mathbf{0 . 4 1 6} \\
0.098\end{array}$ & $\begin{array}{l}\mathbf{0 . 2 3 1} \\
0.064\end{array}$ & & & & & & & & & & & $\begin{array}{l}0.001 \\
0.097\end{array}$ & $\begin{array}{l}0.134 \\
0.101\end{array}$ \\
\hline Europe & $\begin{array}{r}\mathbf{- 0 . 1 3 7} \\
0.035\end{array}$ & $\begin{array}{l}0.067 \\
0.037\end{array}$ & $\begin{array}{r}-\mathbf{0 . 1 3 7} \\
0.045\end{array}$ & & & & & & & & & & $\begin{array}{r}-0.079 \\
0.079\end{array}$ & & \\
\hline Asia & $\begin{array}{r}-\mathbf{0 . 1 7 9} \\
0.030\end{array}$ & $\begin{array}{l}0.028 \\
0.046\end{array}$ & $\begin{array}{r}-\mathbf{0 . 1 4 6} \\
0.028\end{array}$ & & & & & & & & & & $\begin{array}{l}0.106 \\
0.073\end{array}$ & & \\
\hline
\end{tabular}




\section{Table 2B}

Percentage Changes in Region-to-Region Trade Due to NAFTA

\begin{tabular}{|c|c|c|c|c|c|c|c|c|c|c|c|c|c|c|c|}
\hline $\begin{array}{l}\text { Origin/ } \\
\text { destination }\end{array}$ & $\begin{array}{l}\text { Eastern } \\
\text { Canada }\end{array}$ & $\begin{array}{l}\text { Central } \\
\text { Canada }\end{array}$ & $\begin{array}{l}\text { Western } \\
\text { Canada }\end{array}$ & $\begin{array}{c}\text { New } \\
\text { England }\end{array}$ & $\begin{array}{l}\text { Mid- } \\
\text { east }\end{array}$ & $\begin{array}{l}\text { Great } \\
\text { Lakes }\end{array}$ & Plains & $\begin{array}{c}\text { South- } \\
\text { east }\end{array}$ & $\begin{array}{l}\text { South } \\
\text { Central }\end{array}$ & $\begin{array}{l}\text { South- } \\
\text { west }\end{array}$ & $\begin{array}{l}\text { Rocky } \\
\text { Mountain }\end{array}$ & $\begin{array}{l}\text { Far } \\
\text { West }\end{array}$ & Mexico & Europe & Asia \\
\hline Eastern Canada & & & & -10.9 & -3.3 & -5.0 & -17.6 & -10.1 & -14.5 & -9.0 & -20.1 & -15.1 & -14.7 & -16.4 & -16.0 \\
\hline Central Canada & & & & 44.3 & 22.6 & 55.0 & 22.9 & 59.5 & 49.5 & 37.2 & -8.4 & 31.7 & -0.6 & -12.8 & -3.1 \\
\hline Western Canada & & & & -11.4 & -7.2 & 8.9 & 1.5 & -8.8 & -7.4 & -1.5 & 5.3 & 1.7 & 30.9 & -5.8 & -10.1 \\
\hline New England & -12.1 & 16.8 & -13.4 & & & & & & & & & & & & \\
\hline Mideast & -11.0 & 11.4 & -1.2 & & & & & & & & & & & & \\
\hline Great Lakes & -13.0 & 25.7 & 11.6 & & & & & & & & & & & & \\
\hline Plains & -14.6 & 8.5 & 2.3 & & & & & & & & & & & & \\
\hline Southeast & -14.5 & 22.1 & -3.3 & & & & & & & & & & & & \\
\hline South Central & -12.8 & 27.8 & -3.7 & & & & & & & & & & & & \\
\hline Southwest & -14.9 & 9.7 & -0.7 & & & & & & & & & & & & \\
\hline Rocky Mountain & -16.5 & -2.2 & -10.9 & & & & & & & & & & & & \\
\hline Far West & -14.5 & 2.3 & -6.0 & & & & & & & & & & & & \\
\hline Mexico & -12.4 & 51.6 & 26.0 & & & & & & & & & & & 0.1 & 14.3 \\
\hline Asia & -16.4 & 2.8 & -13.6 & & & & & & & & & & 11.2 & & \\
\hline
\end{tabular}




\section{Table 3}

\section{Aggregated Effects of NAFTA on Intra-NAFTA Trade (Percent)}

A. Canada-United States by Canadian Regions

\begin{tabular}{lcc} 
Region & Exports to United States & Imports from United States \\
\hline Eastern Canada & -8.8 & -13.1 \\
Central Canada & 42.8 & 18.3 \\
Western Canada & 0.9 & -0.5 \\
\hline Canada total & 29.2 & 14.3
\end{tabular}

\section{B. Canada-United States by U.S. Regions}

\begin{tabular}{|c|c|c|}
\hline Region & Exports to Canada & Imports from Canada \\
\hline New England & 12.8 & 25.9 \\
\hline Mideast & 9.9 & 16.7 \\
\hline Great Lakes & 23.9 & 47.1 \\
\hline Plains & 6.2 & 9.3 \\
\hline Southeast & 17.1 & 40.9 \\
\hline South Central & 21.7 & 27.9 \\
\hline Southwest & 6.4 & 18.1 \\
\hline Rocky Mountain & -5.8 & 0.6 \\
\hline Far West & -1.7 & 14.4 \\
\hline U.S. total & 14.3 & 29.2 \\
\hline
\end{tabular}

\section{Canada-Mexico by Canadian Regions}

Region

Exports to Mexico

Imports from Mexico

\begin{tabular}{lrr}
\hline Eastern Canada & -14.7 & -12.4 \\
Central Canada & -0.6 & 51.6 \\
Western Canada & 30.9 & 26.0 \\
\hline Canada total & 11.5 & 48.2
\end{tabular}

an even smaller estimated drop in exports to Canada. The results also indicate that the Great Lakes and South Central regions saw the largest increases in exports to Canada, while the largest increases in imports from Canada were for the Great Lakes and Southeast regions.

\section{Canada-Mexico Trade}

As reported in Table 3C, according to the model, NAFTA had a large effect on trade between Mexico and Canada, with significant regional variation. It suggests that, for Canada as a whole, NAFTA increased exports to Mexico by 12 percent and imports from Mexico by 48 percent. However, Eastern Canada saw its exports to and imports from Mexico drop by
15 and 12 percent, respectively, whereas Western Canada saw increases of 31 and 26 percent, respectively. For Central Canada, NAFTA had no effect on exports to Mexico, while it increased imports from Mexico by 52 percent.

\section{Trade Creation?}

As discussed in the introduction, according to the Vinerian dichotomy, NAFTA should have increased the volume of trade between its members, whether these members are countries or regions. Although my results indicate that trade creation held at the country-to-country level, this was far from universal for region-to-region or region-to-country trade. Of the 60 coefficients on intra-NAFTA region-to-region 


\section{Table 4}

\section{Aggregated Effects of NAFTA on Extra-NAFTA Trade (Percent)}

\begin{tabular}{lcr}
$\begin{array}{l}\text { A. Europe } \\
\text { Region }\end{array}$ & Exports to Europe & Imports from Europe \\
\hline Eastern Canada & -16.4 & -12.8 \\
Central Canada & -12.8 & 6.9 \\
Western Canada & -5.8 & -12.8 \\
\hline Canada total & -11.7 & 1.7 \\
\hline Mexico & 0.1 & -7.6
\end{tabular}

B. Asia

\begin{tabular}{lcr} 
Region & Exports to Asia & Imports from Asia \\
\hline Eastern Canada & -16.0 & -16.4 \\
Central Canada & -3.1 & 2.8 \\
Western Canada & -10.1 & 13.6 \\
\hline Canada total & -8.9 & -3.0 \\
\hline Mexico & 14.3 & 11.2 \\
\hline
\end{tabular}

trade, 27 indicate statistically significant decreases in interregional trade because of NAFTA, with 21 of them associated with Eastern Canadian trade. Aggregating the region-to-region effects to the region-tocountry level, negative trade effects also arise: The estimated effect on both directions of Eastern Canada's trade with the United States and Mexico are negative and large. Finally, when the regional effects are aggregated to the country-to-country level, all results have NAFTA leading to an increase in intra-NAFTA trade.

\section{TRADE WITH THE REST OF THE WORLD}

\section{Canada}

As reported in Tables $4 \mathrm{~A}$ and $\mathrm{B}$, the estimated effects of NAFTA on Canada's regional exports to Europe and Asia were, for the most part, consistent with the Vinerian prediction of trade diversion. NAFTA's estimated effects on total Canadian exports to Europe and Asia were decreases of 12 and 9 percent, respectively. Although the magnitude of these effects differed across Canadian regions, the estimated effect on exports to both Asia and Europe were negative for all regions. For both continents, Eastern Canada experienced the largest drops in exports (greater than 16 percent), whereas Western Canada had the smallest drop in exports to Europe
(6 percent), and Central Canada had the smallest drop in exports to Asia (3 percent).

On the import side, the estimated effect of NAFTA on total Canadian imports from Europe was an increase of less than 2 percent, whereas its estimated effect on imports from Asia was a decrease of 3 percent. At the regional level, the results indicate that Eastern and Western Canada both had large decreases in imports from both Europe and Asia, whereas Central Canada saw small and statistically insignificant increases in imports from both continents. So, although the estimated effects of NAFTA on total Canadian imports from each of Asia and Europe were effectively zero, the real story is at the regional level. Consistent with Vinerian trade diversion, the indication is that Eastern and Western Canada both experienced large decreases in imports from Europe and Asia.

\section{Mexico}

As reported in Tables $4 \mathrm{~A}$ and $\mathrm{B}$, the estimated effects of NAFTA on Mexico's exports to the rest of the world were mixed. According to the model, exports to Europe were unaffected by NAFTA, whereas exports to Asia were 14 percent higher. As for Mexican imports, the model suggests that NAFTA led to an 8 percent drop in imports from Europe, whereas it led to an 11 percent increase in imports 
from Asia. Note, though, that none of these estimated effects of NAFTA on Mexican trade with Europe and Asia is statistically significant at traditional levels.

\section{Trade Diversion?}

At the national and regional levels, the effects of NAFTA on Canada's and Mexico's trade with the non-NAFTA world strongly suggests that there has been more going on than simple trade diversion. Although most of the results for Canadian trade are consistent with trade diversion, the story is different for Mexico. In particular, the results indicate that NAFTA has increased the volume of trade with Asia, although the estimated effect on exports and imports are statistically significant at only the 18 and 15 percent levels, respectively.

\section{SUMMARY AND CONCLUSIONS}

According to my results, the effects of NAFTA on the volume and pattern of North American trade have been significant (statistically and otherwise). Specifically, the results indicate that, because of NAFTA, 29 percent more merchandise flowed from Canada to the United States and 14 percent more merchandise flowed from the United States to Canada. Thus, about one-half of the increase in Canadian exports to the United States between 1993 and 1997 is attributed to NAFTA, while about one-quarter of the increase in Canadian imports from the United States over the period is attributed to NAFTA. The results indicate also that NAFTA increased the flow of merchandise from Canada to Mexico by 12 percent and increased the flow from Mexico to Canada by 48 percent. Thus, NAFTA was responsible for about one-quarter of the increase in Canadian exports to Mexico between 1993 and 1997 and roughly 60 percent of the increase in Canadian imports from Mexico over the period.

The volume and pattern of North American trade with Europe and Asia also changed in the wake of NAFTA. Specifically, NAFTA led to large decreases in Canada's exports to Europe and Asia, a decrease in Mexican imports from Europe, and a large increase in Mexican trade with Asia.

The geographical approach reveals interesting regional differences in the effects of NAFTA. For Eastern Canada, NAFTA led to large decreases in trade with the United States, Mexico, Asia, and Europe. For Central Canada, NAFTA led to large increases in trade with the rest of North America and a large decrease in exports to Europe. For
Western Canada, NAFTA had no effect on total trade with the United States, but it did lead to large increases in trade with Mexico and decreases in trade with Europe and Asia. For U.S. regions, the increases in trade were spread widely, with the Rocky Mountain and Far West regions as exceptions.

According to the Vinerian dichotomy, NAFTA should have increased trade between North American regions and decreased trade between each North American region and the rest of the world. Although the gravity methodology is not adequate for separating Vinerian effects from geographic effects, it has provided sufficient evidence that there is more to North American integration than trade creation and diversion. The most significant exceptions to the Vinerian dichotomy were as follows: (i) decreased trade between Eastern Canada and all U.S. regions and Mexico, (ii) decreased trade between Western Canada and some U.S. regions, and (iii) increased trade between Mexico and Asia.

\section{REFERENCES}

Bayoumi, Tamim and Eichengreen, Barry. "Is Regionalism Simply a Diversion? Evidence from the Evolution of the EC and EFTA," in T. Ito and A.O. Krueger, eds., Regionalism versus Multilateral Trade Arrangements. Chicago: University of Chicago Press, 1997.

Bergstrand, Jeffrey $\mathrm{H}$. "The Gravity Equation in International Trade: Some Microeconomic Foundations and Empirical Evidence." Review of Economics and Statistics, August 1985, 67(3), pp. 474-81.

"The Generalized Gravity Equation, Monopolistic Competition, and the Factor-Proportions Theory in International Trade." Review of Economics and Statistics, February 1989, 71(1), pp. 143-53.

Busse, Matthias. "NAFTA's Impact on the European Union." Aussenwirtschaft, September 1996, 51(3), pp. 363-82.

Cheng, I-Hui and Wall, Howard J. "Controlling for Heterogeneity in Gravity Models of Trade and Integration." Working Paper 99-010C, Federal Reserve Bank of St. Louis, 2002 .

Coughlin, Cletus C. and Wall, Howard J. "NAFTA and the Changing Pattern of State Exports." Papers in Regional Science, 2003 (forthcoming).

Deardorff, Alan V. "Testing Trade Theories and Predicting Trade Flows," in R.W. Jones and P.B. Kenen, eds., Handbook of International Economics. Vol. I. New York: Elsevier, 1984. 
"Determinants of Bilateral Trade: Does Gravity Work in a Neoclassical World?" in J.A. Frankel, ed., The Regionalization of the World Economy. Chicago: University of Chicago Press, 1998.

Devadoss, Stephen; Kropf, Jurgen and Wahl, Thomas. "Trade Creation and Diversion Effects of the North American Free Trade Agreement of U.S. Sugar Imports from Mexico." Journal of Agricultural and Resource Economics, December 1995, 20(2), pp. 215-30.

Egger, Peter. "An Econometric View on the Estimation of Gravity Models and the Calculation of Trade Potentials." World Economy, February 2002, 25(2), pp. 297-312.

Eichengreen, Barry and Irwin, Douglas A. "The Role of History in Bilateral Trade Flows," in J.A. Frankel, ed., The Regionalization of the World Economy. Chicago: University of Chicago Press, 1998.

Espinosa, J. Enrique and Noyola, Pedro. "Emerging Patterns in Mexico-U.S. Trade," in Barry Bosworth, Susan M. Collins, and Nora C. Lustig, eds., Coming Together? Mexico-U.S. Relations. Brookings Institution Press, 1997.

Feenstra, Robert C. “World Trade Flows, 1980-1997.” Working paper, Center for International Data at University of California-Davis, 2000.

; Lipsey, Robert E. and Bowen, Harry P. "World Trade Flows, 1970-1992, with Production and Tariff Data." NBER Working Paper No. w5910, National Bureau of Economic Research, 1997.

Frankel, Jeffrey A. "Introduction," in J.A. Frankel, ed., The Regionalization of the World Economy. Chicago: University of Chicago Press, 1998.

Fujita, Masahisa; Krugman, Paul and Venables, Anthony J. The Spatial Economy: Cities, Regions, and International Trade. Cambridge, MA: MIT Press, 1999.

Glick, Reuven and Rose, Andrew. "Does a Currency Affect Trade? The Time Series Evidence." NBER Working Paper No. w8396, National Bureau of Economic Research, 2001.

Gould, David M. "Has NAFTA Changed North American Trade?" Federal Reserve Bank of Dallas Economic Review, First Quarter 1998, O(0), pp. 12-23.

Hanson, Gordon H. "Economic Integration, Intraindustry Trade, and Frontier Regions." European Economic Review, April 1996, 40(3-5), pp. 941-49.
"North American Economic Integration and Industry Location.” Oxford Review of Economic Policy, Summer 1998a, 14(2), pp. 30-44.

"Regional Adjustment to Trade Liberalization." Regional Science and Urban Economics, July 1998b, 28(4), pp. 419-44.

Helliwell, John F. “Do National Borders Matter for Quebec's Trade?" Canadian Journal of Economics, August 1996, 29(3), pp. 507-22.

Hinojosa-Ojeda, Raul; Dowds, Curt; McCleery, Robert; Robinson, Sherman; Runsten, David; Wolff, Craig and Wolff, Goetz. "North American Integration Three Years after NAFTA." North American Integration and Development Center, UCLA, December 1996.

Karemera, David and Ojah, Kalu, "An Industrial Analysis of Trade Creation and Diversion Effects of NAFTA." Journal of Economic Integration, September 1998, 13(3), pp. 400-25.

Kehoe, Patrick J. and Kehoe, Timothy J., eds. Modeling North American Economic Integration: Advanced Studies in Theoretical and Applied Econometrics. Vol. 31. Boston: Kluwer, 1995.

Krueger, Anne O. "Trade Creation and Trade Diversion Under NAFTA.” NBER Working Paper No. w7429, National Bureau of Economic Research, December 1999.

"NAFTA's Effects: A Preliminary Assessment." The World Economy, June 2000, 23(6), pp. 761-75.

Krugman, Paul. Geography and Trade. Cambridge, MA: MIT Press, 1991a.

"Increasing Returns and Economic Geography." Journal of Political Economy, June 1991b, 99(3), pp. 483-99.

"What's New about the New Economic Geography?" Oxford Review of Economic Policy, Summer 1998, 14(2), pp. 7-17.

and Hanson, Gordon. "Mexico-U.S. Free Trade and the Location of Production," in Peter M. Garber, ed., The Mexico-U.S. Free Trade Agreement. Cambridge, MA: MIT Press, 1994, pp. 163-86.

Mátyás, László. "Proper Econometric Specification of the Gravity Model.” The World Economy, May 1997, 20(3), pp. 363-68. 
McCallum, John. "National Borders Matter: Canada-U.S. Regional Trade Patterns." American Economic Review, June 1995, 85(3), pp. 615-23.

Pakko, Michael R. and Wall, Howard J. "Reconsidering the Trade-Creating Effects of a Currency Union." Federal Reserve Bank of St. Louis Review, September/October 2001, 83(5), pp. 37-45.

United States International Trade Commission (USITC). "The Impact of the North American Free Trade Agreement on the U.S. Economy and Industries: A Three Year Review." Investigation No. 332-381, 1997.

Viner, Jacob. The Customs Union Issue. New York: Carnegie Endowment for International Peace, 1950.

Wylie, Peter J. "Partial Equilibrium Estimates of Manufacturing Trade Creation and Diversion Due to NAFTA." North American Journal of Economics and Finance, Spring 1995, 6(1), pp. 65-84.

Data Appendix

\section{DATA SOURCES}

Province-to-state and province-to-country trade data, 1990-98, from Statistics Canada.

Non-Canadian country-to-country trade, 1990-97, from World Trade Flows, 1980-1997.

Nominal gross provincial product, 1990-98, from Statistics Canada.

Nominal gross state product, 1990-98, from the Bureau of Economic Analysis.

Nominal gross domestic product, 1990-98, from the World Bank's World Development Indicators, 1999.

All variables were converted into real Canadian dollars using the Canadian consumer price index (CPI) and \$/C\$ market exchange rates from Statistics Canada.

\section{THE COMPOSITION OF THE REGIONS}

The nine U.S. regions are based on the eight Bureau of Economic Analysis (BEA) regions, with the BEA Southeast region split into two: Southeast and South Central. The three Canadian regions are according to Statistics Canada. The eight countries assigned to the Asia and Europe regions are taken from Canada's ten most important trading partners, the other two being the United States and Taiwan. Taiwan could not be included because the World Bank does not provide its GDP data.

Eastern Canada: New Brunswick, Newfoundland, Nova Scotia, and Prince Edward Island

Central Canada: Ontario and Quebec

Western Canada: Alberta, British Columbia, Manitoba, and Saskatchewan

New England: $\quad$ Connecticut, Maine, Massachusetts, New Hampshire, Rhode Island, and Vermont

Mideast:

Delaware, District of Columbia, Maryland, New Jersey, New York, and Pennsylvania

Great Lakes:

Illinois, Indiana, Michigan, Ohio, and Wisconsin

Plains:

Southeast:

Iowa, Kansas, Minnesota, Missouri, Nebraska, North Dakota, and South Dakota

South Central:

Florida, Georgia, North Carolina, South Carolina, Virginia, and West Virginia

Southwest:

Alabama, Arkansas, Kentucky, Louisiana, Mississippi, and Tennessee

Rocky Mountain:

Arizona, New Mexico, Oklahoma, and Texas

Far West:

Colorado, Idaho, Montana, Utah, and Wyoming

Mexico:

Alaska, California, Hawaii, Nevada, Oregon, and Washington

Asia:

Mexico

Europe:

China, Hong Kong, Japan, and Korea

France, Germany, the Netherlands, and the United Kingdom 


\section{Appendix A}

\section{Table A1}

Percentage Changes in Real Region-to-Region International Trade, 1993-97

\begin{tabular}{|c|c|c|c|c|c|c|c|c|c|c|c|c|c|c|c|}
\hline $\begin{array}{l}\text { Origin/ } \\
\text { destination }\end{array}$ & $\begin{array}{l}\text { Eastern } \\
\text { Canada }\end{array}$ & $\begin{array}{l}\text { Central } \\
\text { Canada }\end{array}$ & $\begin{array}{l}\text { Western } \\
\text { Canada }\end{array}$ & $\begin{array}{c}\text { New } \\
\text { England }\end{array}$ & $\begin{array}{l}\text { Mid- } \\
\text { east }\end{array}$ & $\begin{array}{l}\text { Great } \\
\text { Lakes }\end{array}$ & Plains & $\begin{array}{c}\text { South- } \\
\text { east }\end{array}$ & $\begin{array}{l}\text { South } \\
\text { Central }\end{array}$ & $\begin{array}{c}\text { South- } \\
\text { west }\end{array}$ & $\begin{array}{l}\text { Rocky } \\
\text { Mountain }\end{array}$ & $\begin{array}{c}\text { Far } \\
\text { West }\end{array}$ & Mexico & Europe & Asia \\
\hline Eastern Cana & & & & 37.7 & 62.0 & 71.0 & 33.3 & 130.8 & 12.0 & 104.2 & -4.8 & 3.6 & 0.9 & 11.5 & 38.0 \\
\hline Central Cana & & & & 69.2 & 41.0 & 48.6 & 79.6 & 86.4 & 80.2 & 110.5 & 160.3 & 101.2 & 21.7 & 9.7 & 69.4 \\
\hline Western Can & & & & 81.2 & 36.6 & 48.7 & 59.7 & 53.3 & 71.0 & 125.8 & 82.9 & 42.6 & 90.7 & 35.3 & 27.6 \\
\hline
\end{tabular}

New England

$\begin{array}{lll}40.7 & 45.8 & 50.8\end{array}$

$\begin{array}{llll}\text { Mideast } & 14.3 & 50.7 & 48.3\end{array}$

$\begin{array}{llll}\text { Great Lakes } \quad-15.7 & 41.6 & 33.2\end{array}$

Plains $\quad-47.9 \quad 84.0 \quad 60.5$

$\begin{array}{llll}\text { Southeast } & -4.2 & 63.8 & 63.3\end{array}$

$\begin{array}{llll}\text { South Central } \quad 78.7 \quad 87.6 & 62.8\end{array}$

$\begin{array}{llll}\text { Southwest } & 39.4 & 95.9 & 87.2\end{array}$

Rocky Mountain -39.9 $\quad 46.2 \quad 39.1$

$\begin{array}{llll}\text { Far West } \quad 22.8 & 53.3 & 51.2\end{array}$

$\begin{array}{llll}\text { Mexico } & 26.0 & 69.2 & 219.1\end{array}$

$\begin{array}{llll}\text { Europe } & 45.7 & 49.4 & 109.5\end{array}$

$\begin{array}{lll}\text { Asia } & 23.0 & 28.9\end{array}$

NOTE: Values are the percentage differences in trade between 1997 and 1993, measured in 1992 Canadian dollars at market exchange rates. 


\section{Table A2}

\section{Canada-United States by Canadian Regions}

\begin{tabular}{lcc} 
Region & $\begin{array}{c}\text { Exports to } \\
\text { United States }\end{array}$ & $\begin{array}{c}\text { Imports from } \\
\text { United States }\end{array}$ \\
\hline Eastern Canada & 56.7 & 11.4 \\
Central Canada & 58.4 & 53.7 \\
Western Canada & 55.0 & 51.9 \\
\hline Canada total & 57.6 & 52.7
\end{tabular}

\section{Table A3}

\section{Canada-United States by U.S. Regions}

\begin{tabular}{lcc} 
Region & $\begin{array}{c}\text { Exports to } \\
\text { Canada }\end{array}$ & $\begin{array}{c}\text { Imports from } \\
\text { Canada }\end{array}$ \\
\hline New England & 45.9 & 63.0 \\
Mideast & 49.9 & 41.3 \\
Great Lakes & 40.3 & 48.8 \\
Plains & 74.0 & 67.2 \\
Southeast & 61.2 & 83.5 \\
South Central & 83.8 & 75.4 \\
Southwest & 92.5 & 114.0 \\
Rocky Mountain & 43.2 & 99.0 \\
Far West & 52.0 & 66.9 \\
\hline U.S. total & 52.7 & 57.6
\end{tabular}

Table A4

\section{Canada-Mexico, Europe, and Asia}

Canadian Exports Canadian Imports

\begin{tabular}{lll}
\hline Mexico & 45.6 & 77.7 \\
Europe & 14.6 & 55.7 \\
Asia & 36.4 & 25.9 \\
\hline
\end{tabular}

